\title{
Family Entrepreneurship and Succession
}

A survey in province of Zhejiang

\section{Yue Lin}

\section{OpenEdition}

\section{Journals}

Édition électronique

URL : http://journals.openedition.org/chinaperspectives/1035

DOI : 10.4000/chinaperspectives. 1035

ISSN : 1996-4617

Éditeur

Centre d'étude français sur la Chine contemporaine

Édition imprimée

Date de publication : 1 juillet 2006

ISSN : 2070-3449

\section{Référence électronique}

Yue Lin, « Family Entrepreneurship and Succession», China Perspectives [En ligne], 66 | July- August 2006, mis en ligne le 01 août 2009, consulté le 28 octobre 2019. URL : http://journals.openedition.org/ chinaperspectives/1035; DOI : 10.4000/chinaperspectives.1035

Ce document a été généré automatiquement le 28 octobre 2019.

(c) All rights reserved 


\title{
Family Entrepreneurship and Succession
}

\author{
A survey in province of Zhejiang
}

Yue Lin

1 In The Visible Hand, Alfred D. Chandler reviews the evolution of the organisation and management of production and distribution in the United States since the industrial revolution $^{1}$. He maintains that the modern company, as a complex organisation, has taken the place of market mechanisms in the co-ordinating of economic activity and allocating resources. To Chandler, the theoretician of management capitalism, the visible hand of the managers has replaced the invisible hand of market forces, and the modern company is characterised by the establishment of a hierarchy of salaried cadres who are responsible for supervising and co-ordinating the work of the units that are under their command. Many have reached the conclusion that the company based on family capital and managed by its director-owners is an outdated form. Yet, over the last twenty years, this supposition has been widely called into question by other writers, who recognise the key role played by family businesses in the developed economies. Much research ${ }^{2}$ shows the adaptability of this form of organisation. In mainland China, interest in family businesses was first aroused by the success of the big Chinese family companies which are characteristic of the countries of Southeast Asia ${ }^{3}$, and then by the growth of the Chinese private sector, the majority of whose companies are of the family type ${ }^{4}$.

2 Family business is not characterised by either legal forms or specific size. Some writers choose either the criterion of ownership ${ }^{5}$, or that of management control ${ }^{6}$, in order to describe a business as being a family one or not; other definitions are based on both ownership and control ${ }^{7}$. Recently a dynamic approach ${ }^{8}$ has defined the family business, whether it be a simple family workshop or a big publicly quoted company, in terms of the real control exercised by the founding family. This does not necessarily imply majority control of the capital or the lack of recourse to managers from outside the family. Its distinctive trait is that no other group of shareholders carries greater weight 
than the family shareholders, and that the appointment of the head of the company depends exclusively on the dominant shareholders.

Beyond the question of definition, it is generally agreed that a family business is characterised by the superimposition of a system of enterprise and of a family system in one and the same entity which is both economic and social. The tangling of family and entrepreneurial dynamics calls into question the hypothesis of a homo economicus whose sole objective is the maximisation of his own individual interest. The double identity of the entrepreneur binds his economic activities tightly to the family interests. In matters of succession, a decision is never taken as the result of purely economic calculation, nor is it simply a problem of the passing on of the family inheritance. In order to better grasp the balance of power in a family business, analysis must be based on research in the field, with the objective of interpreting as faithfully as possible the reality as it is perceived by the individuals themselves. In the context of a China in transition where the power of the state mingles with individual motivations, this method makes it possible both to avoid mistakes that would lead to oversimplifying complexities and to shed light on the rich variety of the real lives of individuals and organisations 9 .

The aim of this article is to contribute to the understanding of the present situation of Chinese family businesses, through a focus on the question of succession. In the first part, we introduce a business that has experienced two consecutive succession processes over the last few years. From this we teased out questions which are examined in the second part, in the light of information gathered from 17 family businesses in the province of Zhejiang.

The particular case of the Zhengyuan company

5 The story of the Zhengyuan company is closely tied to that of its founder, You Xiaohui, formerly the director of a state enterprise (the electronic ceramics factory in Jiaxin) and secretary of the enterprise's Party Committee. In April 1993, at the age of 61, he retired and began a second career in Shenzhen. He borrowed 80,000 yuan and became a sales representative for a locality and enterprise at Wuxi. In 1994, he set up his own company, Zhengyuan, with an initial investment of 100,000 yuan, which produced a component for mobile telephones. The company was registered at the Chamber of Commerce and Industry as a collective enterprise ${ }^{10}$. From the outset, despite this official status, Zhengyuan was de facto a private company owned and managed by the You family. All the management jobs were held by members of the family or by close friends. In 1996, Zhengyuan relinquished its status as a collective enterprise and became a public limited company (youxian zeren gongsi) with private capital. In 1999, in accordance with company law ${ }^{11}$, Zhengyuan was restructured and established a board of directors and a supervisory board. In 2000, it became a shareholding company (gufen youxian gongsi). In 2001, Zhengyuan opened its capital to four institutional shareholders, to the tune of 19.5 million yuan, and then prepared its application for a listing on the stock market. In 2002, the company had total capital of 120 million yuan, an annual turnover of 78 million and profits of 11 million. It employs close to a thousand employees.

The founder's family

6 You Xiaohui set up his company at the age of 61 and gave up direct management of it four years later. When asked about his ambitions for Zhengyuan, his first wish was that the company maintain its technological lead over its competitors, develop itself 
sustainably and contribute to local development. These ambitions are evidence that, apart from the creation of personal and family wealth, self-realisation ${ }^{12}$ is a major factor in his entrepreneurial motivation. You Xiaohui is one of those private entrepreneurs who previously had been cadres in state enterprises. He belongs to the professional elites who made a good living before, and who set up private companies in the same sector as that in which they were employed by the state. They are differentiated from entrepreneurs driven by poverty ${ }^{13}$, because of their relatively high incomes ${ }^{14}$. Their professional experience sets them apart from the administrative elites who went into business in order to capitalise on their power at the time of the transition from the planned system to the market system ${ }^{15}$. You Xiaohui thus belongs to the group of private entrepreneurs who most closely resemble the Schumpeterian entrepreneur ${ }^{16}$. They often have a long-term strategy which gives priority to the growth of the company.

7 You Xiaohui has three children: You Yuan (43), his elder son, You Qi (41), his younger son, and his daughter, You Qian (34). You Yuan, who graduated from university in 1982, initially looked after the maintenance of the equipment in a state enterprise, the electric controls factory in Jiaxin. In 1993, he left the company to go into his own electronic equipment business. In 1994, he joined Zhengyuan and became responsible for product design. The same year, You Qi came into the family business with the job of supervising the establishment of the factory. You Qian, who previously worked in a public bank, recently resigned in order to join Zhengyuan. At the time of our research, You Xiaohui was president of the supervisory board, You Yuan and You Qi were respectively president and vice-president of the board of directors, and You Qian was preparing the enterprise's listing on the stock market.

Two transfers of power

8 Over the course of the last ten years, Zhengyuan has experienced two consecutive succession processes. The first chief executive officer of Zhengyuan was You Xiaohui. The job of president of the board at that time was held by his wife. From 1998 onwards, You Xiaohui began the transfer of power to the second generation, appointing his elder son, You Yuan, chief executive officer, and taking over the job of president of the board from his wife. The succession process was completed in 1999 when You Xiaohui resigned the presidency of the board, which he entrusted to You Yuan. This initial succession was carried out by the founder You Xiaohui, who decided to give up the direct management because of his age and the inadequacy of his knowledge in the face of rapid technological developments.

9 The second succession was made necessary by the company's expansion strategy. In 2001, after the modification of the company's legal status, when it became a shareholding company, its development led it to take on "risk capital" to the tune of 19.5 million yuan, and to prepare a request for a listing on the stock market. In order to comply with the criteria of the Chinese Securities Regulation Commission (Zhongguo zhengquan jiandu guanli weiyuanhui) ${ }^{17}$, the company decided to separate the positions held by You Yuan. In order to do this it recruited an outside professional manager, Mr. Cai, who became chief executive officer.

The first transfer of power was a result of the retirement of the head of the company because of his age. If we consider that the main task of a family running a family business is to produce managers with the necessary competencies (knowledge and experience), the interval between two transfers of power within the family will be at 
least twenty-five years in the case of a nuclear family. This interval can be shorter in the case of an extended family, which has the possibility of absorbing sons-in-law or cousins into the company. Thus the structure of the family (the number of children, the availability and motivation of potential successors, etc) influences the frequency of successions.

11 Factors external to the company also come into the calculation. The technological environment demands the renewal of competencies in order to adapt to sectoral evolution. The evolution of the capital structure can expose the company to new shareholders. These factors can contribute to the renewal of the leadership of the company, even if they do not contribute directly to the appointment of the successor.

Even after the arrival of a chief executive officer who was not part of the family circle, the You family, at the time of our interview with You Xiaohui, still held $53 \%$ of the shares, while four financial institutions held $34 \%$, and the other directors $13 \%$. The management team is currently made up of 11 people, of whom three are members of the You family (You Xiaohui and his two sons). Three are former company cadres who now oversee general business, finance and technology. As well as the chief executive officer, three deputy directors have been recruited from outside the company, and an advisory post has been entrusted to a former state employee, who was previously the head of the provincial commission for foreign economic and commercial relations (see Graph 1). Although this evolution has led to a decrease in the control of the founding family, the You family still holds a majority of the capital.

1. Present Organisation of the ZHengyuan Company

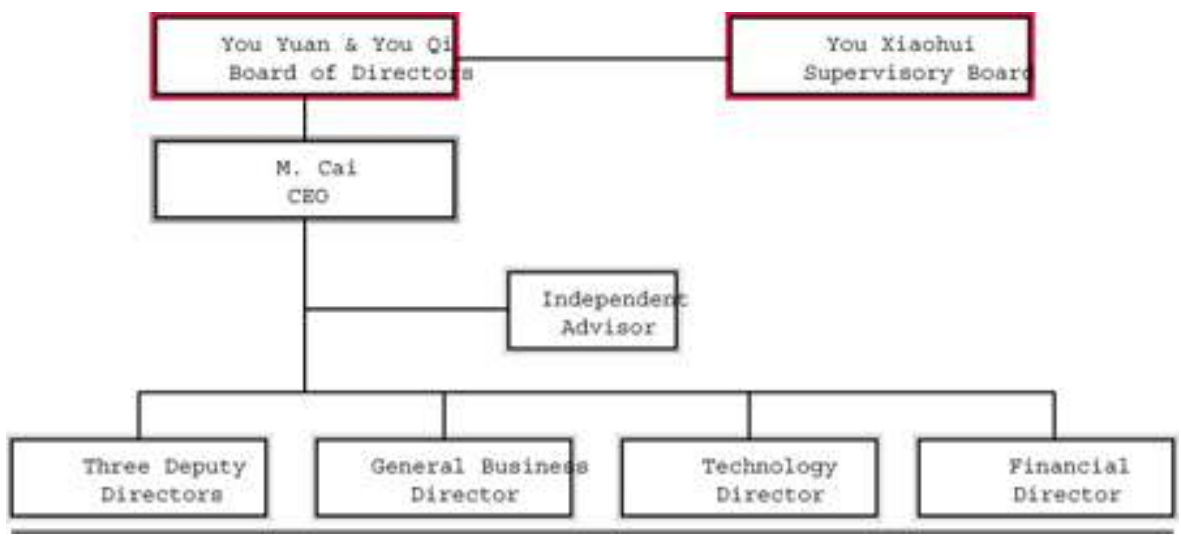

What are the criteria for choosing a successor?

A natural succession linked to the age of individuals is at variance with a succession brought about by the development of the company. The choice of the founder's eldest son differs from the recruitment of a professional from outside the family. Is such a development evidence of a radical change in the criteria used by You Xiaohui in the choice of his successor ${ }^{18}$ ? During our interview You Xiaohui described the desired career profile in the following terms: a competent person with professional experience and a wide network of social contacts. When we asked him to assess the advantages and disadvantages of different modes of selecting a successor (see Table 2), he expressed the opinion that the introduction into the company of a professional manager favoured the strengthening of management and innovation potential; the disadvantage was a lack of knowledge of the moral virtues and the real competence of the person concerned. However if the favoured successor was already a company cadre, You 
Xiaohui would be more certain, thanks to direct knowledge of the competence and moral qualities of the person; the danger was of provoking conflict and slowing innovation. To him, choosing a relation was a guarantee of loyalty and easy communication.

The essential problem of a succession is the assessment of the credibility of the successor, who is asked to provide management competence, but also certain moral values and action taken in accordance with the family interest. The way in which these qualities is assessed is therefore important. In the case of Zhengyuan, You Xiaohui, the founder, first chose his eldest son, You Yuan. A university graduate, initially responsible for product development, he participated in the foundation of the company. His competence is recognised by his family and by the employees. As You Xiaohui sees it, You Yuan is the answer to his expectations: he has the ability to commit himself, loyalty to the family's interests and mastery of the necessary technical and management knowledge. The family connection is not the ultimate reason for You Xiaohui's choice, but it allowed him to observe him closely, to assess him and even to train him. In this sense, the presence of an ideal successor within the family is the reason rather than the result of You Xiaohui's decision to turn over power only four years after the establishment of the company.

15 While the first succession was a strategic move undertaken by the founder, the second succession was prompted by outside forces. In the wake of its change of status in 2000, Zhengyuan took on board new investors from outside. The decision to seek a listing on the stock market led You Yuan to separate the two posts he held, even though this separation was not mandatory. This unexpected development did not allow You Xiaohui easily to observe, assess or train a new successor within the family. The need to designate a successor once again arose at a time when there was no potentially competent person available within the family. You Xiaohui thus found himself in a dilemma ${ }^{19}$ : the designation of an incompetent relative threatens the survival of the company, while the recruitment of a manager outside the family increases the risk of disappropriation, especially in the absence of a legal system capable of settling potential conflicts. In the end, You Xiaohui chose Cai, who had worked for several years in Hong Kong and was previously the director of a state enterprise in Shenzhen. The two men had met in 2000, in the course of business negotiations, and became friends. In 2002, Cai resigned from his company for personal reasons. You Xiaohui then invited him to work at Zhengyuan. Despite other offers from big companies, Cai accepted You's invitation because of their friendly relationship. Cai's professional experience in the sector testified to his competence, which was also confirmed by You Xiaohui's direct observation in their formal and informal relationship. However, just as descendance did not guarantee that You Yuan would automatically become the successor, Cai's professional competence was not enough to convince You Xiaohui to place administrative power in outside hands. Mutual trust, the result of a close personal relationship, played an important role in controlling the risk of disappropriation and allowed You to resolve the dilemma of his succession. The second succession, although carried through outside the family, is still intuitu personae.

Thus professional competence and personal qualities are complementary. While confidence in a person's ability to correctly manage the family patrimony can be established on the basis of indirect information such as reputation, qualifications and professional experience, information on personal qualities is more difficult to obtain. 
Moreover, the uncertainty produced by the imbalance in the available information is increased when the legal system is unable to punish opportunistic behaviour effectively. In this sense, the trust born of personal relationships largely determines the choice of a successor. But the importance given to personal relationships does not mean that an entrepreneur will have blind faith in his children and an absolute distrust of strangers. Trust is a subjective judgement, but it is not immune to reason. The criteria used by You Xiaohui first to choose You Yuan and then Cai are of three kinds: competence, moral qualities and a promise to act according to the family interest. Yuo Yuan's only advantage in comparison with Cai is that he had an intimate relationship with his father since birth, while Cai had to build a relationship with You Xiaohui in order to establish mutual trust. Trust, based on a long relationship, is also a sign of the dynamic nature of a family enterprise which can bring in people from outside the family.

2. You Xiaohui's Perspective on the Choice of a Successor

\begin{tabular}{|c|c|}
\hline Advantage & esDisadvantages \\
\hline $\begin{array}{l}\begin{array}{l}\text { Professional strengtheni } \\
\text { manager } \\
\text { managemen } \\
\text { capabili }\end{array} \\
\text { Innovat }\end{array}$ & $\begin{array}{l}\text { hinofertainty about } \\
\text { his real competer } \\
\text { ties } \\
\text { Uncertainty about } \\
\text { droyalty and mora. }\end{array}$ \\
\hline $\begin{array}{l}\text { Employee already Ease } \\
\text { in the company integrat } \\
\text { Certainty } \\
\text { his pers } \\
\text { qualit }\end{array}$ & $\begin{array}{l}\phi \text { flanger } \\
\text { ion a power strugs } \\
\text { absolutwing of reforn } \\
\text { graid innovation } \\
\text { ies }\end{array}$ \\
\hline $\begin{array}{l}\text { Member } \\
\text { of the family Loyalt } \\
\text { Easy communica } \\
\text { with the fo }\end{array}$ & $\begin{array}{l}\text { y } \\
\text { tion } \\
\text { under }\end{array}$ \\
\hline
\end{tabular}

In China, the development of the private sector goes back less than twenty years, most businesses are family ones and are always run by their founders. The two successions observed in the case of the Zhengyuan company prompted us to formulate the following questions:

Is the recruitment of talent from outside the family merely an illusion in the case of China?

Will the growth of companies lead to the opening up of their capital and what effect will this have on the succession process?

Is the taking into consideration by a family entrepreneur of the loyalty, the spirit of commitment and the professional competence of his successor a widespread phenomenon? 

presence of the founding family in their capital: $44.18 \%$ of the shares belong to the chief executive officers and $41.94 \%$ of the shares are held by other members of the founding family (see Table 3). The chief executive officer is the majority shareholder in nine cases, while the other members of the founding family hold the majority of the capital in the other eight companies. As the chief executive officer is, most often, also the head of the family, the founding families control these companies.

\section{Shareholding}

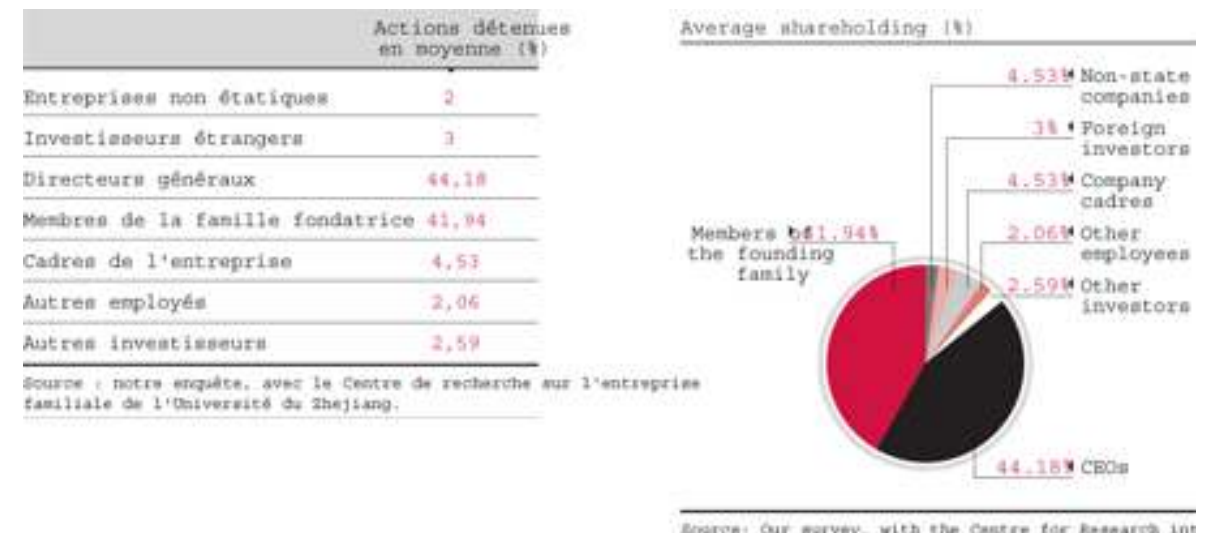

Rovere: Our marvery, with the counth
st the Dhiversity of thejlang.

From the management point of view, executive functions are carried out by the founders (in $40.5 \%$ of cases) and their children (13.8\%), for a total of $54.3 \%$ of positions (see Table 4). Family control at executive level is evident, even if it does not preclude 
the arrival of outside talent ( $25 \%$ of executives are professional managers recruited from outside). The data collected on the capital, the turnover and the number of employees shows that these are large companies (see Table 5).

\section{Excecutive}

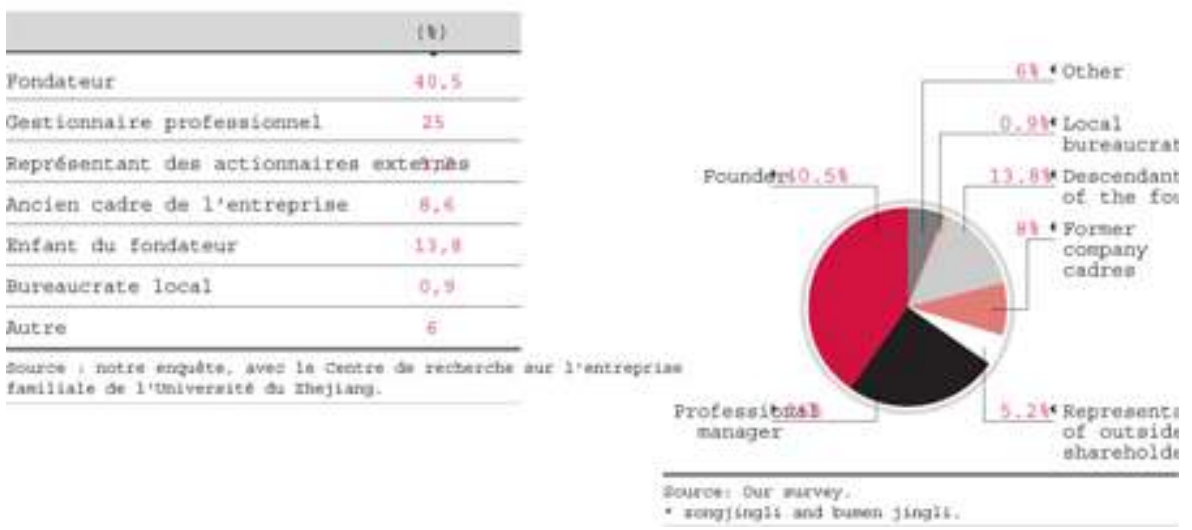

5. Size of Companies in our Survey

\begin{tabular}{|c|c|c|c|c|}
\hline $\begin{array}{l}\text { Number of companies } \\
\text { out of } 17 \text { who replied }\end{array}$ & & Average & Minimus & Maximum \\
\hline 11 & $\begin{array}{l}\text { Total capical } \\
\text { (in thourande of yuan) }\end{array}$ & 97.281 .5 & 22,634 & 281,117 \\
\hline 13 & $\begin{array}{l}\text { Total curnover } \\
\text { [in thousands of yuan] }\end{array}$ & $135.204: 2$ & 16,800 & 550,000 \\
\hline 13 & Number of employeea & 872 & 2SB & 2,500 \\
\hline
\end{tabular}

Eource i our marvey.

The reasons for succession

At the time of our survey, the majority of family businesses were still under the control of their founder. $88.2 \%$ of the founders were aged between 40 and 50 . The transfer of power between generations is therefore not yet a major preoccupation. However, $82.4 \%$ of the founders (14 out of 17) admitted that they have already begun to look for their successors. When asked for their reasons, only nine companies expressed an answer (see Table 6).

6. The reasons for succession

\begin{tabular}{|c|c|c|}
\hline & Level of & Importance \\
\hline Necesafties of development & Insufficiency of managettent competence & 40.5 \\
\hline \multicolumn{2}{|c|}{ Personal unguitability to the preshngaituation } & 25 \\
\hline & - Lack of knowledge & 5.2 \\
\hline & - Ininess & 18.6 \\
\hline & - Loat of interent & 13.8 \\
\hline Descendanta' wishes & Descendanta' atrong desire to join the & compasy 9 \\
\hline \multicolumn{2}{|c|}{ Presaures of the external environmentemands by out Bide investors } & 6 \\
\hline
\end{tabular}

The main reason is linked to the founder himself. The physical decline due to age (28.9\%) is the major reason, while a recognition of the limitations of his competence in the face of technical evolution ranks second $(28.3 \%)^{23}$. Some also refer to the external 
environment in a situation where growth no longer allows the founder, despite his competence, to control his company alone. A lack of management capability within the company obliges him to consider a transfer of power (5.9\%). Lastly, outside investors may demand a change of leadership, but the influence they exert remains limited (5.9\%). The reason may lie in the closed nature of the capital: the family businesses in this survey mainly rely on self-financing $(90 \%)$ or on bank loans $(69.4 \%)$ for finance ${ }^{24}$. Whatever the reasons for this ${ }^{25}$, the closed nature of the capital of these companies and the very limited impact of outside investors on the choice of chief executive, lead us to believe that the Zhengyuan company is a very particular case. Its decision to seek a stock market listing must be seen as an evolution in the personal preferences of certain members of the family. In other words, the choice of certain family businesses to become bigger and more "modern", with the help of the financial markets, is more the result of particular personal decisions than a law of the development of family businesses ${ }^{26}$.

Thus, the physical decline of the founder and the evolution in the technical environment are the two main factors that lead to succession taking place, while the direct pressure exerted by outside investors is marginal. The role played by the second generation at this stage of the succession must also be noted. To the question "Do your children wish to work and progress in your company?", 76.5\% of the founders give a positive reply, but none of them envisage giving up their power only because of their children's desire to participate more in the business.

The criteria for choosing a successor

Although the children's desire to share power with their parents does not automatically allow them to succeed to the job of chief executive, $88.2 \%$ of founders want their children to be able to work in the company. This apparent contradiction demonstrates the complexity of the criteria that apply in the choice of a successor. In order to identify them, three categories of qualities were listed in the questionnaire. We asked the founders to list them in declining order of importance, and then calculated their respective levels of importance (see Table 7) ${ }^{27}$.

Loyalty (50.4\%), leadership ability (50\%) and the spirit of commitment (43.8\%) are the most appreciated qualities. Experience (26.1\%) and university training ((19.5\%) are also deemed important. Also mentioned is the network of professional contacts (15.8\%). If one compares the level of importance of the three categories, "character traits" come first (28.8\%), "abilities" follow (at 17.5\%), while "other qualities" come last (2.6\%). In the choice of a successor, moral qualities and technical competence are the two main criteria taken into account by the founders. However, morality seems more important than competence in the eyes of the majority of founders ${ }^{28}$.

31 The importance given to loyalty and competence is differentiated according to the kind of responsibility taken on. Where the post of chief executive, the most important in day-to-day management, is concerned, opportunistic behaviour is the most harmful to the interests of the family. Where the manager's loyalty and spirit of commitment are the most important criteria, the selection of a successor always remains subjective, despite the objective aspect of the selection procedure which is partly based on an assessment of competence through university training and acquired experience. Similar assessments are made in other parts of the world. Both in developed countries, such as Canada, and developing countries, such as India, loyalty and the spirit of commitment are deemed to be the most important qualities by company heads ${ }^{29}$. 


\begin{tabular}{|c|c|c|}
\hline \multicolumn{3}{|c|}{ Level of importance } \\
\hline \multirow{4}{*}{$\begin{array}{l}\text { Charact } \\
\text { traits }\end{array}$} & er Loyalty & 50.4 \\
\hline & - Spirit of commitment & 43.8 \\
\hline & - Other traits* & 16.2 \\
\hline & - Creativity & 4.8 \\
\hline \multirow[t]{6}{*}{ Abilitie } & es Leadership abilitity & 50 \\
\hline & - Experience in the same sector & $r 26.1$ \\
\hline & - Higher education & 19.5 \\
\hline & - Linguistic knowledge & 5.1 \\
\hline & - Age & 4.4 \\
\hline & - Specialisation (Finance, HR, & commer \\
\hline \multirow{6}{*}{$\begin{array}{l}\text { Other } \\
\text { qualiti }\end{array}$} & - Network of professional conta & $\operatorname{actss} 8$ \\
\hline & - Authority within the company & 0 \\
\hline & - Good relations with local gov & vernmer \\
\hline & - Knowledge of political regula & ations \\
\hline & - Reputation & 0 \\
\hline & - Youth & 0 \\
\hline \multicolumn{3}{|c|}{$\begin{array}{l}\text { *Companies A and B consider "other traits" to be the " } \\
\text { while Company C ranks "other traits" in fifth place. } \\
\text { Entrepreneur A explains that "the will to work" is mos } \\
\text { while entrepreneur B considers that "an accommodating } \\
\text { and entrepreneur C expects his successor to "work hard }\end{array}$} \\
\hline
\end{tabular}

Thus the challenge facing a chief executive is to assess credibility and to measure the moral risks ex poste. In contemporary China, institutional trust ${ }^{30}$ is deemed to be insufficient because of the low power of constraint of the institutional framework. Trust intuitu personae and relationship trust ${ }^{31}$ are the two main forms of trust which the Chinese establish in economic and social life. When formal structures do not make it possible to produce "calculable trust" resulting from a rational calculation, which consists of accurately predicting the behaviour of others through the constraints of the situation, trust "only begins, can only be measured and is only consistent in lasting social relationships"32. "The social connection network is the organising principle in Chinese companies" ${ }^{33}$.

Trust is a continuous process that evolves along with the behaviour of the players, the stakes, their power and the emergence of new rationalities ${ }^{34}$. The complexity of the information obtained by an employer is thus a function of personal relationships. Resorting to members of the family during the development phase of a company is thus the result of a "stronger trust between family members than between commercial partners" 35 . The founder of an enterprise has at his disposal more information about the members of his family than about the employees he has already recruited, and, even more so, than about someone from outside.

34 Table 8 examines the advantages and disadvantages of choosing a successor by taking into account the degree of "proximity". Family entrepreneurs share a common vision of the various means of recruitment. They believe that the main advantage of recruiting a professional manager is that it favours innovation, while the main disadvantage lies in the uncertainty about the person's loyalty and honesty. Internal promotion and recruiting a family member for succession favour the continuity of the 
company culture, making it possible for the founder to reduce the risk of recruiting a person with weaker moral values than hoped for. However, internal recruitment may slow innovation and the reforms necessary in order to adapt to technical evolution. The loyalty of relations is recognised by most founders as being the highest (61.3\%).

8.Advantages and Disadvantages of the Ways of Selecting a Successor

\begin{tabular}{|c|c|c|}
\hline Loved of 1 & Importand & terat of topertat \\
\hline - Intreduetion of new tdeal & 45,4 & - Incersainty about loyaley and other infral qualistell \\
\hline - strengthening of eanagenent abilis & itsea & - Dasger of contriet with exployeea 42 \\
\hline \multicolumn{3}{|c|}{ - Sindiar proteasional protile to these tsunderoifficuleien of integration } \\
\hline - Innovation & 25.2 & - tack of adaptability to the conpaby ait taire \\
\hline - Reniutance to internal prenaruren & 7.5 & - Danger of divulging combercial secreven 6 \\
\hline \multirow[t]{2}{*}{ - Reduction of pown utruggies } & 5.3 & - Defending his own intereat: S, s \\
\hline & 5. & $\begin{array}{l}\text { - Uncertality about hiz real conpetence } \\
\text { - ochera }\end{array}$ \\
\hline \multicolumn{2}{|l|}{ - Cechexs } & - ocbera \\
\hline \multicolumn{3}{|l|}{ fateznal zetruitenant } \\
\hline \multicolumn{3}{|l|}{ Advantageil } \\
\hline \multicolumn{2}{|c|}{ - Easy integratico 53.9} & - Cocbervatias \\
\hline \multicolumn{2}{|c|}{ - Certalaty about persogal qualieiea 44.1} & - Danger of power atrugglen \\
\hline \multicolumn{2}{|c|}{ - coatibuity of managenent styie 34.3} & - sloving of retorn \\
\hline \multicolumn{2}{|c|}{ - Lopq-tern visico 27.5} & - Emergence of tactiona \\
\hline \multicolumn{2}{|c|}{ - Eary nobiliestion of informal renouareal } & , \\
\hline - ochers & 3.9 & - ocbers \\
\hline \multicolumn{3}{|c|}{ Retrultane of a tanily nutber } \\
\hline \multicolumn{3}{|c|}{ Advantages Lavel of inportand bimatvancoagn } \\
\hline \multicolumn{2}{|c|}{ - Loyalsy si.3 } & - tack of competence \\
\hline \multicolumn{2}{|c|}{ - Easy cemminteation with the founderss.4 } & - Obetacle to the lotroduction of outatibs zalent \\
\hline \multicolumn{2}{|c|}{ - protectice of coenereial aecreta 26.9} & - Decreave in the notivation of otper eqpioyen \\
\hline \multicolumn{3}{|c|}{ - Hartwoey between the fanily and ochezo atplogefenpervatias } \\
\hline - Harnoeny witbin the tanily & 15.2 & - sloxing of reforti \\
\hline - Continaity of managenme styln & 3. 3 & \\
\hline - ochers & 21 & - ochera \\
\hline
\end{tabular}

Consequently, the ideal successor in the eyes of a founder is a relation who is both motivated and competent. This is borne out by our observation, since the majority of those questioned during our survey explicitly stated that the best solution is to pass power on to the descendants who have already proved their professional competence and their spirit of commitment. Problems arise when the ideal candidate is unavailable and when professional competence is the key to the success of the company. The means on which the founders rely in order to check the moral aspect of candidates, if the designated successor is not a relation, are not clear. Nevertheless, our hypothesis according to which personal relationships constitute an informal way of checking the reliability of a successor, is partially justified by the results of the surveys carried out by other researchers. Li Guoqing has shown that $45 \%$ of chief executives are either relations $(42 \%)$ or friends $(3 \%)$ of the chief executive, $25 \%$ are cadres recruited internally, while only $16 \%$ are directly recruited on the job market ${ }^{36}$.

Beyond the case of the Zhengyuan company, the survey carried out reveals that in Chinese family businesses, the reasons for succession, the criteria of selection of the successor and the order of preference among the various candidates all conform with practices in other parts of the world. In the course of the development of their enterprise, the founders do not hesitate to entrust functional jobs to competent third parties who are not members of the family circle. However, it is to be expected that the succession to the job of chief executive officer will usually be the result of the natural retirement of the head of the company. Anxious to preserve his patrimony, an 
entrepreneur in China, as elsewhere, while taking into account technical competence and management abilities, assesses above all the honesty and loyalty of his potential successor. Trust, in the widest sense of the word, is a decisive factor. Consequently, the entrepreneur prefers to designate a competent member of his family.

It is when such a successor is not available at the time of succession that the particularity of China's case becomes more marked; this is not linked to cultural specificities, but to the institutional context ${ }^{37}$. The underdeveloped state of institutions

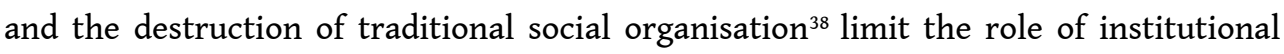
trust in economic co-operation. In contemporary China, trust is usually produced by personal relationships. Social networks are brought into action in order to control the risks in the face of uncertainty ${ }^{39}$. The case of the Zhengyuan company and the opinions we have gathered show the entrepreneur resorting to his network of relationships when his successor is being chosen. Depending on the degree of intimacy of the relationship, he first seeks a candidate among "the members of his family" then among "those close to him", and may finally resort to "strangers". The wide-ranging definition of zijiren, which includes all those deemed reliable and sharing common values, makes it possible for a family business to escape the dilemma of succession and to develop even if there is a lack of available professional managers. The survey did not make it possible to answer all the questions arising from the case of the Zhengyuan company. Our sample was limited, and could not determine how representative it is of the majority of private companies, which in reality are small in size. Moreover, the question of succession remains open. Further surveys will provide wider knowledge and understanding of this area of business in China.

Translated from the French original by Michael Black

\section{NOTES}

1. Alfred D. Chandler, The Visible Hand: The Managerial Revolution in American Business, Cambridge, Harvard University Press, 1977.

2. A search of the bibliographical data base ABI-PROQUEST using the key words "family businesses" shows an increase in the number of articles published: 33 articles prior to 1989, 110 between 1990 and 1999, and 195 articles during the period 2000 to 2003.

3. The work of the historian Wong Siu-lun is ground-breaking. Cf. in particular Wong Siu-lun, "The Chinese Family Firm: A Model", The British Journal of Sociology, Vol. 36, No. 1, 1985, pp. 58-72.

4. "1997 nian quanguo siying qiye chouyang diaocha shuju ji fenxi" (Analysis and Data of Research into Private Companies Nationwide in 1997), in Zhang Houyi (ed.), Zhongguo siying qiye fazhan baogao 1978-1998 (Report on the Development of Private Companies in China, 1978-1998), Beijing, Shehui kexue wenxian chubanshe, 1999, pp. 131-168; "Woguo siying qiye guanli yu kongzhi moshi fenxi ji qi wanshan duice" (Analysis of the Governance and the Means of 
Control of Chinese Private Companies), in Zhang Houyi (ed.), Zhongguo siying qiye fazhan baogao 1999 (Report on the Development of Private Companies in China, 1999), Beijing, Shehui kexue wenxian chubanshe, 2000, pp. 122-148; "Siying qiye zhili jiegou wenjuan diaocha de shuju yu fenxi" (Analysis and Data of the Questionnaire on the Governance Structure of Private Companies), in Zhang Houyi (ed.), Zhongguo siying qiye fazhan baogao 2001 (Report on the Development of Private Companies in China, 2001), Beijing, Shehui kexue wenxian chubanshe, 2002, pp. 166-193. The four volumes of Zhongguo siying qiye fazhan baogao bring together studies carried out over the last ten years of the capital and governance structure of Chinese private companies. This research shows that in the companies surveyed, over $80 \%$ of the capital belongs to the entrepreneur and to his family, that $60 \%$ of entrepreneurs are owneroperators, and that $55 \%$ of chief executive officers are relatives or close friends of the entrepreneur. See also Gan De'an, Zhongguo jiazu qiye yanjiu, Beijing, Zhongguo shehui kexue chubanshe, 2002.

5. Louis B. Barnes and Simon A. Hershon, "Transferring Power in the Family Business", Harvard Business Review, Vol. 54, July-August 1976, pp. 105-114. ; I. Lansberg, S. Perrow, and S. Rogolsky, "Family Business as an Emerging Field", Family Business Review, Vol. 1, 1988, pp. 1-8.

6. Wendy. C. Handler, "Methodological Issues and Considerations in Studying Family Businesses", Family Business Review, Vol. 2, pp. 257-276.

7. C. E. Aronoff, J. L. Ward, Family Business Sourcebook, Detroit, MI, Omnigraphics, 1990.

8. J.H. Chua, J.J. Chrisman, P. Sharma, "Defining the Family Business by Behavior", Entrepreneurship Theory and Practice, Vol. 23, 1999, pp. 19-39; Ye Yinhua, "Jiazu konggu jituan, hexin qiye yu baochou hudong zhi yanjiu" (Research on Family-controlled Groups, Companies and Remuneration), Guanli pinglun, Vol. 18, No. 2, 1999.

9. For another survey of family business in China, cf. Gilles Guiheux, "The Revival of Family Capitalism”, China Perspectives, No. 58, March-April 2005, pp. 22-31. The perspective is one of the production of a discourse of justification. 10. This was often the case during the first years of reform. Private capital companies were registered as public capital companies (and were described as "wearing a red hat", dai hongmaozi) for reasons both political (recognition by the authorities) and financial (access to loans from state banks). Cf. Gilles Guiheux, "The Incomplete Crystallisation of the Private Sector", China Perspectives, No. 42, July-August 2002, pp. 24-35.

11. This was the gongsifa in 1993, which was applied only to companies (limited liability companies and limited companies) and made mandatory the establishment of a general assembly, a board of directors and a supervisory board.

12. Schumpeter sees this as being the principal driving force of entrepreneurs. 13. See the Global Entrepreneurship Monitor, a research programme which distinguishes between two kinds of entrepreneur. The "opportunity pull entrepreneur" is motivated by hopes of maximum profit and a desire to take advantage of opportunities; setting up a business is the result of personal 
preference. The "poverty push entrepreneur" is motivated by the lack of any alternative; setting up a business is an imperative, not a free choice.

14. Andrew G. Walder shows that during the first decade of the reforms, the "privatisation" of the economy was marked by the rise of family workshops. It was individuals without any entrepreneurial experience who were most drawn to private enterprise, because that was where they found the fastest way to accumulate personal resources. The heads of publicly-owned companies did not enter the private sector until the first privatisations of public companies, in the second decade. Andrew G. Walder, "Privatization and Elite Mobility: Rural China 1979-1996", working paper, Asia/Pacific Research Center, Stanford University, Stanford, 2002.

15. The professional elite contrasts with the administrative elite. The latter were more tempted than the professional elite to enter the private sphere during the first stage of reform, when administrative power and personal contacts were more important for entrepreneurial success. The professional elite, however, were more inclined to set up their own businesses when technologies became more advanced and the market mechanisms were already established. See Lu Zheng, "Entry into the Emerging Private Sector. An Institutional Analysis of Entrepreneurship in Urban China", working paper, Department of Sociology, Stanford University, Stanford, 2004.

16. Schumpeter distinguishes three forms of motivation in the entrepreneur: the dream and the desire to found a private kingdom, the will to win, and the joy of creating a new economic form. Joseph Schumpeter, The Theory of Economic Development, Piscataway, NJ, Transaction Publishers, 1982.

17. On January 9th 2002, the Securities Regulation Commission imposed the first norms for the governance of listed companies (Shangshi gongsi zhili zhunze, norms of governance of listed companies). The separation of the functions of president of the board of directors from that of chief executive officer was not obligatory. Nevertheless, the modified version published in the Zhongguo zhengquan on January 10th 2002 asked all the listed companies to comply with the principle according to which "the president of the board of directors and the chief executive officer must not be the same person".

18. As head of the family, You Xiaohui maintained a very important influence in the question of succession. It was he, and not You Yuan, president of the board of directors, who proposed Cai as his second successor.

19. Lee K.S., Lim G.H., Lim W.S., "Family Business Succession: Appropriation Risk and Choice of Successor", The Academy of Management Review, Vol. 28, No. 4, 2003, pp. 657-666.

20. My most sincere thanks go to Professor Chen Lin and to Mrs Ying for welcoming me into their team and sharing information with me.

21.Cf. http://www.stats.gov.cn/tjbz/qyhxbz/t20030528_80450.htm. According to these criteria, all companies which employ more than 300 people, and for which the annual turnover is in excess of 30 million yuan, or the assets exceed 40 million yuan are considered to be medium or large companies. On the problems of classifying private companies in China, cf. Thierry Pairault, "La renaissance des PME chinoises" [The Renaissance of Chinese SMEs], Actes des 
Neuvièmes Journées scientifiques du réseau Entrepreneuriat de l'AUF, ClujNapoca, 1er-4 juin 2005.

22. According to a survey carried out in 1999 by the Federation of Industry and Commerce of Zhejiang province, private companies established after 1990 amount to $67.1 \%$ of the total, and those established between 1980 and 1989 to $30 \%$. The average age of the entrepreneur was 41 . Entrepreneurs aged between 30 and 39 amount to $40.9 \%$ of the total, those aged between 40 and 49 to $35.5 \%$. Xie Liping (ed.), Zhejiang siying jingji yanjiu (Research on The Private Economy of Zhejiang), Hangzhou, Zhejiang renmin chubanshe, 2000, p. 92 and p. 201.

23. Only $11.8 \%$ of founders have received higher education, and fewer than $50 \%$ have secondary education qualifications.

24. The series of reports on private companies published under the direction of Zhang Houyi and the Zhongguo siying jingji nianjian 1997-1999 (Annual of the Chinese Private Economy 1997-1999, Beijing, Huawen chubanshe, 2000) shows that individual investment and self-financing amounted to over $90 \%$ of financing during the 1990S.

25. Mike Burkart, Fausto Panunzi and Andrei Shleifer, "Family Firms", The Journal of Finance, Vol. 58, 2003, pp. 2167-2202; J.S. Ang, W.L. James and T. Floyd, "Evidence of the Lack of Separation Between Business and Personal Risks Among Small Businesses", Journal of Small Business Finance, Vol. 4 (2/3), 1995, pp. 197-210.

26. Miguel Ángel Gallo, Josep Tàpies et Kristin Cappuyns, "Comparison of Family and Nonfamily Business: Financial Logic and Personal Preferences", Family Business Review, Vol. 17, 2004, pp. 303-318.

27. The level of importance was calculated to assess not only the dispersion but also the preference of respondents vis-à-vis the variables being tested. We asked respondents to choose the reasons which made them think about succession and to list them in declining order of importance. We gave each reason a mark which corresponds to its rank in the listing. We then calculated the average mark of each reason and determined the level of importance according to the formula: real average mark/reference mark. The reference mark depends on the number of variables being tested. Since these were qualitative variables, we supposed that all the variables had the same level of importance for all the respondents. The calculation of the "level of importance" in the other Tables follows the same logic.

28. These results closely resemble those of a survey carried out in 1995. Cf. Chu Xiaoping, Jiazu qiye de chengzhang yu shehui ziben de ronghe, Beijing, Jingii kexue chubanshe, 2004, p. 75.

29. J.J. Chrisman, J.H. Chuae and P. Sharma, "Important Attributes of Successors in Family Businesses: An Exploratory Study", Family Business Review, Vol. 11, 1998, pp. 19-34; P. Sharma and A. Srinivas Rao, "Successor Attributes in Indian and Canadian Family Firms: A Comparative Study", Family Business Review, Vol. 13, 2000, pp. 313-330.

30. As defined by Williamson ("Calculativeness, Trust, and Economic Organization", Journal of Law \& Economics, Vol. 36, April 1993, pp. 453-486), "institutional trust" refers to the social and organisational context in which contracts are made. "Personal trust" is defined as the trust which comes into 
play in non-commercial relationships, which is to say, family, friendship or love relationships. The quasi-uncalculating nature of personal trust is deemed to be particularly connected to the costs associated with the destruction of the "atmosphere".

31. Zucker ("Production of Trust: Institutional Sources of Economic Structure", in B. M. Staw \& L. L. Cummings (eds.), Research In Organizational Behavior, Greenwich, CT, JAI Press, 1986) distinguishes three forms of trust according to their mode of production: trust intuitu personae, which draws on the particular characteristics of individuals; relationship trust, as a particular belief in the actions or the result of actions undertaken by others, which is based on past or anticipated exchanges, depending on reputation; and institutional trust, which is linked to a formal structure which guarantees the specific attributes of an individual or of an organisation.

32. Wong Siu-lun, "Chinese Entrepreneurs and Business Trust", in Gary G. Hamilton, Asian Business Networks, Berlin, Walter de Gruyter, 1996, pp. 13-24. 33. Kao Cheng-shu, "Personal Trust in The Large Businesses in Taiwan: A Traditional Foundation for Contemporary Economic Activities", in Gary G. Hamilton, op. cit., pp. 61-69.

34. Peng Siqing, "Xinren de jianli jizhi: guanxi yunzuo yu fazhi shouduan" (Trust Mechanisms: Personal Relationships and the Law), Shehui xue yanjiu, No. 2, 1999, pp. 53-66.

35. Sun Wenbin and Wong Siu-lun, "Bufen jiazu qiye de diaocha yu fenxi", in Zhang Houyi (ed.), Zhongguo siying qiye fazhan baogao 2002 (Report on the Development of Private Companies in China 2002), Beijing, Shehui kexue wenxian chubanshe, 2003, p. 138.

36. Li Guoqing, "Siying qiye zhili jiegou wenjuan diaocha de shuju yu fenxi" (Analysis and Data of the Questionnaire on the Governance Structure of Private Companies), in Zhang Houyi (ed.), 2002, op. cit., pp. 166-193.

37. Francis Fukuyama, Trust: The Social Virtues and the Creation of Prosperity, New York, Free Press, 1995.

38. Collectivisation, followed by the Cultural Revolution and recent urbanisation have to large extent destroyed the initial order of rural society, which entrusted the elders of a village with the power of arbitration. 39. Here we refer to Fei Xiaotong, according to whom Chinese society is based on social networks. Fei uses two metaphors to compare Western society with Chinese society: "Western society is like a haystack, while Chinese society is made up of waves in the form of concentric circles, as when one throws a stone into water". Each individual is at the centre of a circle, and weaves his own network in an extensive fashion, from family members to close friends, to professional colleagues. Fei Xiaotong, Xiangtu Zhongguo, Beijing, Sanlian shudian, 1985 (first published in 1948). 


\section{RÉSUMÉS}

In mainland China, the family, as the basic social unit, has recently regained its importance in economic activity. Starting from the particular case of a family business located in Zhejiang province, this article reviews the practices that prevail in the succession of the management of companies. Following this case study, a questionnaire was drawn up and submitted to 17 family businesses. The criteria applied by the entrepreneur in the choice of his/her successor, the order of preference among the candidates, and the methods of controlling the risks involved are revealed and analysed. 